\title{
Environmental and Physiological Variables During the Catching of Broilers
}

http://dx.doi.org/10.1590/1516-635x170137-44

\section{-Author(s)}

Queiroz ML de V

Barbosa Filho JAD"

Duarte LM"'I

Brasil $D$ de $F$

Gadelha CRF"II

Departamento de Engenharia Agrícola, UFC, CCA/UFC - Campus do Pici, Bloco 804, CEP 60455-760. Fortaleza, CE, Brasil. E-mail: marilialvqueiroz@gmail.com. Autor para correspondência.

" Programa de Pós-graduação em Engenharia de Sistemas Agrícolas, Universidade Federal do Ceará (UFC), Fortaleza, CE, Brasil.

III Departamento de Zootecnia, Universidade Federal do Ceará (UFC), Fortaleza, CE, Brasil.

\section{Mail Address}

Corresponding author e-mail address Marília Lessa de Vasconcelos Queiroz

Alphaville Eusébio, Rodovia CE-040, Km 22, Qd. B1, s/n. Pires Façanha | CEP 61.760 903 - Eusébio - Ceará. Phone/Fax: (5585) 32411307 or (5585) 31019848 or (5585) 96549405

E-mail: marilialvqueiroz@gmail.com

\section{nKeywords}

Animal welfare, environment, poultry, preslaughter, rectal temperature.

\section{ABSTRACT}

The objective of this study was to determine the critical points of the operation of broiler catching for transport to the processing plant from animal and operational perspectives. During catching, chickens, environmental variables (temperature and relative humidity) were constantly monitored to determine the Enthalpy Comfort Index (IEC). Also, the physiological variable rectal temperature (RT) was monitored as an indicator of stress suffered by the birds during this handling procedure. Bird welfare were evaluated by analyzing their behavior. The bag method was effective to prevent the struggling of birds while being taken from the broiler house to the transport truck, reducing physical injuries and losses during catching.

\section{INTRODUCTION}

According to the Annual Report of Brazilian Poultry Association (UBABEF) published in 2014, Brazil is currently the third largest global broiler producer and occupies the largest exporter of chicken meat. Around $68.4 \%$ of the production is domestically consumed, and $31.6 \%$ is exported. The Brazilian poultry industry has always made heavy investments in technological improvements to increase production. Despite these investments, losses still occur. Some of these losses happen during the pre-slaughter stage, when several of the applied handling practices may be harmful because they compromise broiler welfare, survival, and carcass quality. According to Rocha et al. (2008), pre-slaughter handling affects broiler welfare, causing $90 \%$ of the injuries observed by the health inspection service.

Catching in one of the most critical stages of the pre-slaughter period because broilers are exposed to a high degree of stress and may suffer from bruises, scratches, and fractures, which result in carcass downgrading and even death of the birds. Therefore, care should be taken to minimize losses during this phase, particularly to the environmental conditions. The temperature of the internal environment of poultry houses is essential for the success of catching in regions with predominance of high temperatures all year long (Lavor et al., 2008). This stresses the need for paying greater attention to factors related to poultry homeostasis during catching in order to prevent performance losses and poor bird welfare. This study aimed at evaluating and determining broiler stress during catching.

\section{MATERIAL AND METHODS}

The experiment was conducted by the NEAMBE (Animal Welfare and Agricultural Environment Study Group - UFC) in October, 2011, on a broiler farm belonging to a broiler company. According to the Köppen classification, the climate of the experimental area is $A w^{\prime}$, 
with $26^{\circ} \mathrm{C}$ average temperature. The geographical coordinates of the evaluated broiler house are latitude $4^{\circ} 13^{\prime} 20^{\prime} \mathrm{S}$, longitude $38^{\circ} 12^{\prime} 1^{\prime}$ ' $\mathrm{W}$. The catching of broilers was evaluated in one broiler house with the following dimensions: $12 \mathrm{~m}$ width, $100 \mathrm{~m}$ length, 2.30 $\mathrm{m}$ ceiling height, and $1.00 \mathrm{~m}$ eaves, with a capacity of 9,000 broilers. The roof was covered with ceramic tiles, no dropped ceiling, the sides were open and covered with $40-\mathrm{cm}$ high plastic curtains. The housed was equipped with ventilation fans and foggers, which were turned manually on at the hottest hours of the day, bell drinkers, and tube feeders. No pen divisions were used. The litter consisted of sand and wood shavings. Broilers were Ross ${ }^{\circledR 3} 38$ and six weeks old at the time of catching. The catching operation was evaluated in the morning (08:00 to 11:59) and in the afternoon (12:00 to 15:59).

\section{Environmental variables}

Temperature $\left({ }^{\circ} \mathrm{C}\right)$ and relative humidity (\%) inside and outside the broiler house were monitored every minute by data loggers installed at inside the house and outside the broiler house. The equipment was set 0.5 $\mathrm{m}$ from ground level at the center of the broiler house and slightly higher than the broilers' height in order to obtain representative readings of the conditions to which the birds were submitted.

\section{Thermal comfort index}

The thermal comfort index is a measure of the enthalpy expressed as the amount of thermal energy in $\mathrm{kJ}$ contained in $1 \mathrm{~kg}$ dry air. Thermal comfort index is used to quantify and classify birds' thermal discomfort, which may affect their physiological responses and live performance (Damasceno et al., 2010). The applied enthalpy equation was that proposed by Rodrigues et al. (2010), which includes temperature $\left({ }^{\circ} \mathrm{C}\right)$, relative humidity (\%) and local barometric pressure $(\mathrm{mmHg})$ values. The Enthalpy Table, developed by Queiroz et al. (2012), was used for the practical evaluation of the Enthalpy Comfort Index (ECI) of six-week-old broilers reared in regions located at sea level.

\section{Rectal temperature of broilers}

The rectal temperature $\left(\mathrm{RT}\right.$, in $\left.{ }^{\circ} \mathrm{C}\right)$ was the main physiological variable evaluated during the experiment, aiming at determining the thermal comfort physiological response of broilers inside the broiler house before, during, and after catching. In general, innermost body regions have more constant temperature, whereas surface regions present more variable temperature, as they are more influenced by the external environment (Silva, 2000). Rectal temperature was determined by inserting a digital thermometer into the cloaca of seven broilers for one minute or until temperature stabilization before, during, and after catching in the morning and in the afternoon.

\section{Statistical analysis}

This study was designed to be a quantitative, experimental, and cross-time (Appolinário, 2010). According to this author, a cross-time study is made with only a single collection of data, with different groups of subjects. This number of broilers analyzed during each phase of the experiment allowed for the normality of the sample distribution, which was assessed for skewness and kurtosis, according to Hines et al. (2006).

In order to determine if there were significant differences in rectal temperature, before, during, and after catching, data were compared by the test ofusing the Tukey test, using the software MINITAB ${ }^{\circledR}$ 15.0.

\section{Behavioral parameters}

The behavior of broilers during the catching procedure was continuously recorded using a digital camera for later analysis of their behavior during the catching. The videos were analyzed to observe the reaction of the birds to catching and to describe their behaviors. Although the birds move constantly during catching, the videos allowed the observation and interpretation of behavior.

\section{Bag method - description of catching}

The farm evaluated in this study does not adopt the procedure of fasting before the catching. Birds are not fasted because they are sold live for small processing plants, where birds are then fasted during lairage. One hour before catching started, the rectal temperature of seven randomly selected broilers randomly selected was measured to determine their temperature under normal conditions. During catching, foggers were turned off and the fans remained operating to minimize the discomfort caused by the dust produced inside the broiler house while birds and people moved. Broilers inside catching circles were caught in twos by the back (Japanese method) and placed in bags that carried seven birds each.

During catching, birds were transported from inside the broiler house to the outside inside bags made of yellow canvas $(50-\mathrm{cm}$ long, $30-\mathrm{cm}$ wide, with top opening of a maximum of $60 \mathrm{~cm}$ ). Bags started to be used on the farm to prevent catchers from excessively handling the birds, thereby preventing carcass damage and to avoid bringing transport crates inside the broiler house, because they may be a source of contamination of broiler litter. 
While inside the bags, broilers were weighed and then placed into the transport crates. The bag containing broilers was weighed to determine average broiler body weight. The same amount of birds placed into the bags was placed into the crates. A crate may carry six or seven birds, depending on broiler age and weight; the number is reduced as broiler age and weight increase. In this experiment, seven birds were transported by bag. The time of permanence of broilers inside the bags varied according to the distance between the catching circle and the place where the truck was parked. Rectal temperature was also measured when the broilers were inside the bags, and was considered the rectal temperature during catching. The birds were then placed inside a transport crate, where they remained for 20-30 minutes. When the catching was nearly finished, the rectal temperature of the broilers inside the crate was measured again, and was considered as the rectal temperature after catching.

\section{RESULTS AND DISCUSSION}

Catching time varied according to the amount of birds to be caught per shift. In the morning, catching lasted $01 \mathrm{~h} 05 \mathrm{~min}$ and $01 \mathrm{~h} 10 \mathrm{~min}$ in the afternoon. Average body weight during catching was $3.371 \mathrm{~kg}$ in the morning and $3.257 \mathrm{~kg}$ in the afternoon.

\section{Environmental variables}

According to Macari \& Furlan (2001), the optimal temperature range for six-week-old broilers is between $21-24^{\circ} \mathrm{C}$. The temperature of $24^{\circ} \mathrm{C}$ is considered as the upper limit of Thermal Stress (UL), and the temperature of $21^{\circ} \mathrm{C}$ as the lower limit of Thermal Stress (LL). During both shifts evaluated, the environmental temperature was higher than $24^{\circ} \mathrm{C}(\mathrm{UL})$, which may affect broiler thermal comfort (Figure 1). Higher temperatures were observed in the afternoon, as expected.

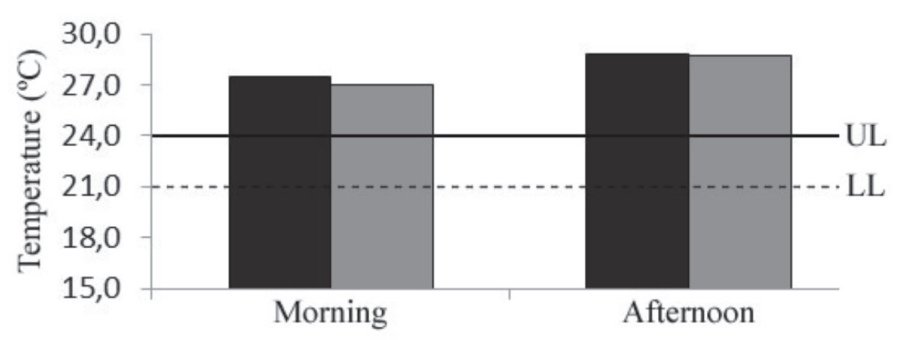

Shift

$$
\square \text { Tshed } \square \text { Toutside }
$$

Figure 1 - Mean values of the environmental variable in temperature inside and outside the broiler house evaluated in two shifts, morning and afternoon. (UL - Upper Limit of thermal stress and LL - Lower Limit heat stress).
During the afternoon, the temperature inside the broiler house was $28.8^{\circ} \mathrm{C}$ and outside was $28.7^{\circ} \mathrm{C}$. In the morning, values were somewhat lower, $27.5^{\circ} \mathrm{C}$ inside, and $27.0^{\circ} \mathrm{C}$ outside the broiler house. These results are consistent with those reported by Barbosa Filho (2008), who found higher temperatures inside and outside of broiler houses in the afternoon. That author also suggested that the pre-slaughter handling during the afternoon shift more harmful as birds may suffer from heat stress.

According to Macari \& Furlan (2001), optimal relative humidity for broiler production is around $60 \%$, and values below $40 \%$ and above $80 \%$ are critical. Relative humidity of $75 \%$ is considered as the upper relative humidity limit (UL) and $60 \%$ as the lower relative humidity limit $(\mathrm{LL})$. The relative humidity values measured during both shifts in the present experiment were higher than the optimal value recommended (Figure 2).

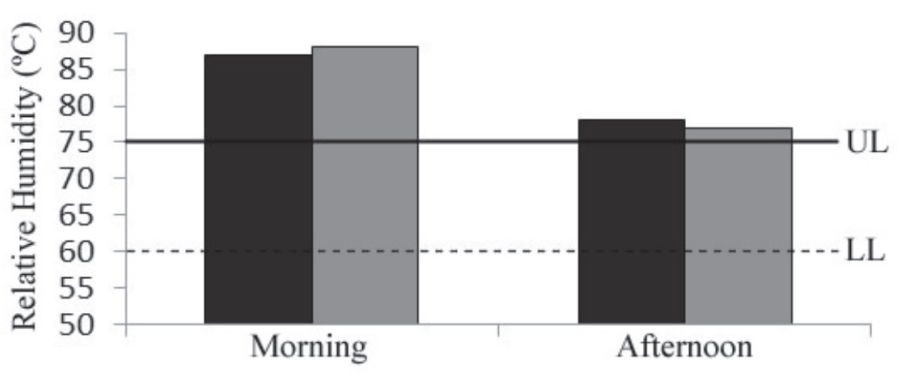

Shift

a RHshed $\square$ RHoutside

Figure 2 - Mean values of the environmental variable relative humidity inside and outside the broiler house evaluated in two shifts, morning and afternoon. (UL - Upper Limit of thermal stress and LL - Lower Limit heat stress).

In the morning, relative humidity was $87 \%$ inside and $88 \%$ outside the broiler house. In the afternoon, relative humidity was $78 \%$ inside and $77 \%$ outside the broiler house. Relative humidity in the morning was higher due the occurrence of rainfall at the time of data collection. Barbosa Filho (2008) recorded relative humidity values below $80 \%$ inside the broiler house in the morning, which was also associated with the occurrence of rainfall at the time of data collection. The increase in relative humidity may affect the thermal comfort of broilers, because it impairs the evaporative heat loss. The greater the relative humidity, the more difficulty broilers have to remove the internal heat through the airways, leading to increased respiratory rate (Oliveira et al., 2006). 


\section{Thermal comfort index}

Using the recorded temperature and relative humidity data, thermal condition was classified according to the Enthalpy Comfort Index (ECI) for six-week-old broilers. The $\mathrm{ECl}$ includes four thermal comfort and stress ranges: the comfort zone is between $37.4-52.1 \mathrm{~kJ} / \mathrm{kg}$ dry air, the warning zone is between $52.2-63.0 \mathrm{~kJ} / \mathrm{kg}$ dry air, the critical zone is between $63.1-72.6 \mathrm{~kJ} / \mathrm{kg}$ dry air, and the lethal zone is above $72.7 \mathrm{~kJ} / \mathrm{kg}$ dry air (Queiroz et al., 2012).

During catching, the $\mathrm{ECl}$ was calculated for the inside and the outside of the broiler house every ten minutes. During the morning catching, $\mathrm{ECl}$ values were higher than $78 \mathrm{~kJ} / \mathrm{kg}$ dry air both inside and outside the broiler house. These values are in the lethal zone, a condition that causes extreme stress for the birds. Under this condition, broilers may develop polypnea and eventually die (Medeiros et al., 2005).

In the afternoon, average $\mathrm{ECl}(78 \mathrm{~kJ} / \mathrm{kg}$ dry air) was lower than in the morning, but still in the lethal zone. This value indicates that the thermal conditions inside the broiler house were very poor, because the combination of high temperature and high relative humidity can cause broilers to die. When submitted to thermal stress, depending on the magnitude and duration, broilers present high prostration and mortality rates (Moura, 2001). Silva et al. (2007) observed that the duration of exposure to high temperature and high relative humidity significantly influences broiler rectal temperature (RT) and respiratory rate. According to those authors, broilers submitted to high temperature and high relative humidity tended to present higher RT values as exposure time increased.

\section{Rectal temperature of broilers}

According to Macari \& Furlan (2001), $41.1^{\circ} \mathrm{C}$ is the lower rectal temperature limit of heat stress and when this value is exceeded, broilers are under heat stress, suffering physiological changes to try to maintain optimal body temperature. These physiological changes negatively affect live performance. Broilers with rectal temperature above $46.3^{\circ} \mathrm{C}$ usually die (Silva et al., 2007). Average RT recorded during catching in the morning and afternoon shifts was $42.9^{\circ} \mathrm{C}$ and $41.2^{\circ} \mathrm{C}$, respectively, exceeding the limit of $41.1^{\circ} \mathrm{C}$, evidencing heat stress. Barbosa Filho (2008) obtained, in the summer, mean RT values of $41.6^{\circ} \mathrm{C}$ and $42.6^{\circ} \mathrm{C}$ during catching in the morning and in the afternoon, respectively. RT values of broilers obtained during the catching in the present study were close to those mentioned by that author.

\section{Statistical evaluation of rectal temperature of broilers}

As shown in Table 1, kurtosis and symmetry coefficients of RT before, during, and after catching, in both shifts, were within the range -2 and 2 , fitting to a normal distribution curve, according to Hines et al. (2006).

Table 1 - Descriptive statistics of rectal temperature (RT) during catching in the morning and in the afternoon.

\begin{tabular}{|c|c|c|c|c|c|c|}
\hline \multirow[t]{3}{*}{ Variables } & \multicolumn{6}{|c|}{ Rectal temperature $\left({ }^{\circ} \mathrm{C}\right)$} \\
\hline & \multicolumn{2}{|c|}{ Before catching } & \multicolumn{2}{|c|}{ During catching } & \multicolumn{2}{|c|}{ After catching } \\
\hline & Morning & Afternoon & Morning & Afternoon & Morning & Afternoon \\
\hline Observations & 7 & 7 & 7 & 7 & 7 & 7 \\
\hline Mean $\left({ }^{\circ} \mathrm{C}\right)$ & 40.6 & 40.5 & 42.9 & 41.2 & 43.1 & 41.9 \\
\hline $\mathrm{SD}\left({ }^{\circ} \mathrm{C}\right)$ & 0.287 & 0.141 & 0.535 & 0.195 & 0.503 & 0.439 \\
\hline Variance & 0.082 & 0.0200 & 0.286 & 0.0381 & 0.253 & 0.193 \\
\hline CV $(\%)$ & 0.71 & 0.35 & 1.25 & 0.47 & 1.17 & 1.05 \\
\hline Range $\left({ }^{\circ} \mathrm{C}\right)$ & 0.800 & 0.400 & 1.700 & 0.600 & 1.600 & 1.200 \\
\hline Skewness & -0.37 & 0.00 & 0.59 & 0.28 & -0.36 & 1.31 \\
\hline Kurtosis & -0.32 & -1.20 & 1.34 & 0.04 & 0.90 & 1.59 \\
\hline
\end{tabular}

SD - standard deviation and CV - coefficient of variation. 
Table 2 presents the results of the $\mathrm{F}$ test, which show that RT means were different at $5 \%$ significance level between the two shifts.

Table $\mathbf{2}$ - Analysis of variance in rectal temperature (RT) during the morning and afternoon.

\begin{tabular}{lccccc}
\hline Variables & DF & SS & MS & $F$ & $\frac{\text { Test F }}{\mathrm{P}}$ \\
\hline \multicolumn{5}{c}{ Morning } \\
\hline Factor & 2 & 27.570 & 13.785 & 66.55 & 0.000 \\
\hline Error & 18 & 3.729 & 0.207 & \\
\hline Total & 20 & 31.298 & & \\
\hline & & & Afternoon \\
\hline Factor & 2 & 6.4467 & 3.2233 & 38.53 & 0.000 \\
\hline Error & 18 & 1.5057 & 0.0837 & \\
\hline Total & 20 & 7.9524 & & \\
\hline
\end{tabular}

DF - degrees of freedom, SS - sum of squares and MS - mean square.

Means were then compared by the test of Tukey, and Table 3 shows recta temperature results relative to catching time and shift.

Table 3 - Comparison of rectal temperature (RT) relative to catching time and shift.

\begin{tabular}{lcc}
\hline RT $\left({ }^{\circ} \mathrm{C}\right)$ & Morning & Afternoon \\
\hline Before catching & $40.6 \pm 0.287 \mathrm{~A}$ & $40.5 \pm 0.141 \mathrm{~A}$ \\
\hline During catching & $42.9 \pm 0.535 \mathrm{~B}$ & $41.2 \pm 0.195 \mathrm{~B}$ \\
\hline After catching & $43.6 \pm 0.503 \mathrm{~B}$ & $41.9 \pm 0.439 \mathrm{C}$ \\
\hline
\end{tabular}

Means followed by equal letters in the same column are not statistically different by Tukey's test $(p<0.05 \%)$.

Mean RT values increased during the experimental period. Similar results were found by Silva et al. (2007), who obtained a mean RT of $40.3^{\circ} \mathrm{C}$ in broilers before heat stress, and this value increased as heat stress conditions became more severe. As expected, the lowest mean RT was obtained before catching, and higher RT means during and after catching. Rectal temperature values before catching did not exceed $41.1^{\circ} \mathrm{C}$, which is the lower heat stress limit for broilers. This demonstrates that birds were not under heat stress before catching started.

The mean RT values obtained during and after catching in the morning shift were not statistically different, whereas mean RT values measured at the three different catching times in the afternoon were different from each other. Mean RT values during and after the catching in both shifts exceeded $41.1^{\circ} \mathrm{C}$, indicating that broilers increase body temperature when exposed to adverse and stressful situations. These results agree with those of Garcia et al. (2007), who verified a significant increase in broiler stress during the catching, as evaluated by the increase in RT.

In the two shifts, the RT of broilers reached higher values after the catching, while inside the transport crates. As mentioned earlier, the rain probably caused the higher RT in the morning shift than in the afternoon. Then, due to high relative humidity during the morning, birds were under greater stress both during and after the catching. Therefore, the RT measured during those phases did not differ statistically. Barbosa Filho (2008) recorded during transport crate loading in the summer, RT values of $41.8^{\circ} \mathrm{C}$ and $42.7^{\circ} \mathrm{C}$ in the morning and in the afternoon, respectively. Placing broilers inside the crates is a stressful procedure due to the confinement and mixture with unknown birds, and causes some physiological changes indicative of stress (Knowles \& Broom, 1990).

\section{Behavioral parameters}

When catching started, catching crews entered in the broiler house, causing broilers to stir and disperse until the end of catching. Some behaviors were quite evident and widespread, such as vocalization, escape attempts and panting. Paranhos da Costa (2006) reported that environmental factors may influence the responsiveness of birds. Some of these factors are aggressive handling and the lack of habituation of broilers to humans, which may increase the intensity of their reactions. That author also observed that panic reactions are more common during critical moments of handling, such as during catching. On this farm, the transport crates were not used to form the catching circles to prevent contamination of broiler litter by the crate because they are used in the external environment of the farm. In this case, a hinged-metal fence was used to trap the birds.

Inside the circle, birds tended to cluster on the corners and sometimes began to pile up, climb over each other in an attempt to escape. This crowding is detrimental to broiler welfare and carcass quality because birds may get hurt and, when climbing on each other, their nails may cause skin lesions. While being caught, some broilers struggled, but most could not 
do it because their wings were held and immobilized, because they were caught by the back. After being placed inside the bags, birds remained quiet and moved little. The low light inside the bag may have contributed to calm the birds during catching. Jones et al. (1998) analyzed strategies to reduce panic in birds, and one alternative was to cover their heads with a hood to reduce visibility. Those authors found that the use of hood virtually eliminated struggling. According to Gregory \& Bell (1987), there are strong evidences that reducing light intensity calms down the birds.

In addition to reduced light intensity, the other factor that may have contributed for the little movement of birds inside the bags was the reduced space, which did not allow the birds to move. Jones et al. (1998) observed reduced struggling of broilers shackled in the processing line when a heavy curtain was suspended from the overhead conveyor. The authors concluded that the heavy curtain limited the movement of birds or that they remained motionless due to the continuous tactile stimulus from the curtain. In the present study, bags allowed continuous tactile stimulus, representing a physical obstacle that prevented wing flapping and vision, and were very effective in minimizing and reducing the harmful effects of panic reactions. This immobilization during catching probably helped reducing carcass injuries and improved broiler welfare, and it is one of the reasons why this method is used on this farm. Improving the welfare of poultry is a goal of the poultry industry, since there is a growing demand for animal products from systems that treat animals humanely (Rocha et al., 2008).

Upon being placed in the transport crates, broilers vocalized and flapped wings trying to escape. Some of the birds hit the crates, which caused carcass damages, especially to wings that were more exposed. After some time inside the crates, birds became quieter, static, because no movement was possible inside the crates, and all remained panting. According to Barbosa Filho (2008), during loading and transport, birds may be exposed to low ventilation and high temperature, and the accumulation of water vapor resulting from panting compromises the efficiency of evaporative heat loss and effectively increases the thermal load on birds. Therefore, loading and transport also exert a strong influence on the welfare of broilers.

\section{CONCLUSIONS}

1. The time when broilers were more susceptible to heat stress was during and after catching, as demonstrated by the increase in broiler rectal temperature.
2. The morning shift proved to be the least adequate for catching, probably due to rainfall, resulting in high relative humidity values.

3. The bag method was effective to prevent the struggling of birds while being taken from the broiler house to the transport truck, and this will certainly aid reducing physical injuries and losses during catching.

4. Broilers should not remain too long inside the bags, since there is a risk of worsening heat stress and of death by asphyxia.

The experiment was approved by the Ethics Committee on Animal Research (CEPA) of the Federal University of Ceará (UFC), \# 70/2012, and complies with the law and the Ethical Principles published by the Brazilian College of Animal Experimentation (COBEA).

\section{REFERENCES}

Appolinário F. Metodologia da ciência: filosofia e prática da pesquisa. São Paulo: Cengage Learning; 2010.

Barbosa Filho JAD. Caracterização quantiqualitativa das condições bioclimáticas e produtivas nas operações pré-abate de frangos de corte [thesis]. Piracicaba (SP): Universidade de São Paulo; 2008.

Damasceno FA, Yanagi Junior T, Lima RR, Gomes RCC, Moraes SRP. Avaliação do bem-estar de frangos de corte em dois galpões comerciais climatizados. Ciência e Agrotecnologia 2010; 34:1031-1038.

Garcia DB, Hildebrand A, Barbosa Filho JAD, Vieira FMC, Vieira AMC, Silva IJO. Avaliação da temperatura retal durante a operação de pega pré-abate de frangos de corte. Simpósio Internacional de Iniciação Científica da USP; 2007; Pirassununga, Sao Paulo. Brasil: Universidade de São Paulo; 2007.

Gregory NG, Bell JC. Duration of wings flapping in chickens shackled before slaughter. Veterinary Records 1987;121:567-579.

Hines WW, Montgomery DC, Goldsman DM. Probabilidade e estatística na engenharia. $4^{a}$ ed. Rio de Janeiro: LTC; 2006

Jones RB, Satterlee DG, Cadd GG. Struggling responses of broiler chickens shackled in groups on a moving line: effects of light intensity, hoods, and curtains. Applied Animal Behaviour Science 1998;58:341-352.

Knowles TG, Broom DM. The handling and transport of broilers and spent hens. Applied Animal Behaviour Science 1990;28:75-91.

Lavor CTB, Fernandes AAO, Sousa FM. Efeito de materiais isolantes térmicos em aviários no desempenho de frango de corte. Revista Ciência Agronômica 2008;39:308-316.

Macari M, Furlan RL. Ambiência na produção de aves em clima tropical. In: Silva IJO, editor. Ambiência na produção de aves em clima tropical. Piracicaba: FUNEP; 2001. v.1, p.31-87.

Medeiros CM, Baêta FC, Oliveira RFM, Tinôco IFF, Albino LFT, Cecon PR. Efeitos da temperatura, umidade relativa e velocidade do ar em frangos de corte. Engenharia na Agricultura 2005;13:277-286.

MINITAB. MINITAB Statistical Software, Release 15 for Windows. Pennsylvania: State College; 2009 
Moura DJ. Ambiência na produção de aves de corte. In: Silva IJO, editor. Ambiência na produção de aves em clima tropical; Piracicaba: FUNEP; 2001. v.1, p.75-148.

Oliveira RFM, Donzele JL, Abreu MLT, Ferreira RA, Vaz RGMV, Cella PS. Efeitos da temperatura e da umidade relativa sobre o desempenho e o rendimento de cortes nobres de frangos de corte de 1 a 49 dias de idade. Revista Brasileira de Zootecnia 2006;35:797-803.

Paranhos da Costa MJR. Etologia e produtividade animal. Brasília: Associação Brasileira de Zootecnistas, 2006.

Queiroz MLV, Barbosa Filho JAD, Vieira FMC. Avaliação do conforto térmico de frangos de corte de forma direta e prática. Revista Produção Animal - Avicultura 2012;21-24.
Rocha JSR, Lara LJC, Baião NC. Produção e bem-estar animal: Aspectos éticos e técnicos da produção intensiva de aves. Ciência Veterinária nos Trópicos 2008;11:49-55.

Rodrigues VC, Silva IJO, Vieira FMC, Nascimento ST. A correct enthalpy relationship as thermal comfort index for livestock. International Journal of Biometeorology 2010;455-459.

Silva RG. Introdução à bioclimatologia animal. São Paulo: Nobel; 2000

Silva MAN, Barbosa Filho JAD, Silva CJM, Rosário MF, Silva IJO, Coelho AAD, Savino VJM. Avaliação do estresse térmico em condição simulada de transporte de frangos de corte. Revista Brasileira de Zootecnia 2007;36:1126-1130.

União Brasileira de Avicultura. Relatório Anual 2010/2011. Available from: http://www.uba.org.br 
